\title{
Aberrant PI3K Signaling Pathway in Urinary Bladder Cancer
}

\author{
Srivastava $\mathrm{AN}^{1}$, Siddiqui $\mathrm{Z}^{2 *}$, Sankhwar $\mathrm{SN}^{3}$, Raza $\mathrm{ST}^{4}$ and Fatima $\mathrm{N}^{2}$ \\ ${ }^{1}$ Era University, India \\ ${ }^{2}$ Department of Pathology, Era University, India \\ ${ }^{3}$ Department of Urology, King George's Medical University, India \\ ${ }^{4}$ Department of Biochemistry, Era's Lucknow medical college and hospital, India
}

Submission: February 22, 2017; Published: May 02, 2017

*Corresponding author: Zainab Siddiqui, Department of Pathology, Era University, Lucknow, India, Email: zainab.siddiqui6@gmail.com

\begin{abstract}
In India UBC is the fifth most common cancer in men. UBC is categorized into non-invasive and muscle- invasive types. Recurrence and multifocality are the two common features of UBC. PI3K pathway is known as the survival pathway and it inhibits the apoptotic proteins. Some studies have revealed its potential role in bladder cancer progression and survival. In UBC this pathway is constitutively expressed. The mutations in downstream proteins of PI3K pathway include PTEN, PI3KCA, Akt and TSC1. These mutated genes are responsible for the severity of the disease.
\end{abstract}

Keywords: Bladder cancer; PI3K; Akt; mTOR; PTEN; Cell cycle inhibitors; Apoptosis; Cell signaling

Abbreviations: UBC: Urinary Bladder Cancer; PI3K: Phosphatidylinositol 3-kinase.

\section{Introduction}

Urinary Bladder Cancer (UBC) ranks ninth among all cancers and is one of the common cancers worldwide with highest incidence in industrialized countries. According to American Cancer Society in 2015, there will be 74,000 (about 56,320 men and 17,680 women) new cases of UBC and 16,000 (about 11,510 men and 4,490 women) people will die of this disease in USA [1]. In India it is the fifth most common cancer among men with incidence rate of 5.8cases/100,000 person year according to Delhi based registry. But in females incidence is much lower (1.5cases/100,000 person year) [2]. It is an outcome of multifactorial process that includes genetic and/or non-genetic risk factors, thus influencing the progression, angiogenesis, metastasis and invasion of the bladder cancer cells. Genetic risk factors include personal or family history of cancer, deletions on chromosome 3, 8, 9, 11, 13, 17 [3] and mutations in several genes such as CCND1 [4], FGF3 [4,5], FGF4 [4] , GST-M1, NAT2 [5,6] HRAS [7,8], KRAS, NRAS, FGFR3, PIK3CA [8], PTEN [9]. While non-genetic factors include occupational exposure to carcinogenic substances like aromatic amines and polycyclic aromatic hydrocarbons [10,11], smoking habits [12,13], some drugs like diabetic medications [14] or chronic bladder inflammation [15]. It has been found that both the genetic and non-genetic risk factors have cumulative effect in the occurrence of UBC like polymorphism in glutathione S-transferase and $\mathrm{N}$-acetyl transferase gene in cigarette smokers modulates the risk $[16,17]$. UBC is pathologically classified into transitional cell carcinoma $(90 \%)$ and the remaining $(10 \%)$ into squamous cell carcinoma, adenocarcinoma, sarcoma and rare variety like small cell carcinoma [18]. Approximately $70-75 \%$ of UBCs [19] are non-invasive which are treated by transurethral resections but they have a tendency to recur and progress into invasive \& metastatic carcinomas which limits the 5year survival rate to $69 \%$ [20]. The remaining $25-30 \%$ of UBCs [19] are muscleinvasive at the time of first detection but they become more aggressive \& metastatic later which results in sharp depreciation of 5 year survival rate from $34 \%$ to $6 \%$ respectively [20]. Thus recurrence and multifocality are the two common features of UBC.

\section{Phosphatidylinositol 3-kinase (PI3K) signaling pathway}

It is a significant cell signaling pathway that regulates various cellular functions like cell growth, proliferation and survival. 
The two main features of PI3K pathway are anti-apoptosis and cell proliferation which are achieved by inhibition of apoptotic as well as cell division regulatory proteins respectively. But in a wide range of cancers this pathway is expressed continuously without its feed-back regulation. The various components of this pathway include PTEN, AKT, PI3K and mTOR which prove to be therapeutic targets in many Phase I clinical trials. Several studies have reported alterations in PI3K pathway in UBC. The mutation rates of genes in this pathway include PI3KCA (24\% of superficial tumors) [8], PTEN (24-58\% of high grade tumors) [9], AKT (2.7\%) [21] and TSC1 (>50\%) [22] gene. Thus it is worthwhile to study the cell signaling pathway which governs cell survival i.e. PI3K pathway. As recurrence and multifocality are the two common features of UBC therefore targeting PI3K pathway will be beneficial in reducing mortality rate.

\section{Discussion}

UBC has high recurrence rate which necessitates researches to study its molecular pathogenesis and develop novel targets for effective treatment. As PI3K signaling pathway is involved in uncontrolled cell proliferation in UBC therefore it posses potential for therapeutic target. The most common alteration of PI3K pathway include mutations in catalytic subunit PI3KCA, Akt and loss of PTEN. The mutation in PI3KCA has been found to be significantly associated with superficial tumors [8]. Akt activity remains elevated in bladder cancer cells as examined in UM-UC-3 and T24 cell lines [23]. Apart from mutations in genes micro-RNA too have role in targeting this pathway. It has been found that down regulation of microRNA-126 fails to inhibit PI3K pathway and thus promotes cell invasion in bladder cancer cell line [24]. The germline mutations in PI3K pathway have found to be predicting prognosis in higher stages of UBC. Chen $\mathrm{M}$ et al. [25] studied 20 genes of PI3K pathway out of which only three single nucleotide polymorphism of AKT2 rs3730050, PIK3R1 rs10515074, and RAPTOR rs9906827 genes were associated with the survival of UBC patients. PTEN is a tumor suppressor and regulates PI3K pathway. Few studies on immunohisto chemistry have reported a decreased protein expression of PTEN in UBC [26]. Some bladder cancer cells uptake Bacille Calmette-Guerin while some are resistant to it. The uptake of BCG is mediated by PI3K pathway [27].

\section{Conclusion}

From this review we conclude that PI3K pathway plays a crucial role in pathogenesis of bladder cancer. The alterations in this pathway will benefit in developing targeted therapy.

\section{References}

1. Siegel RL, Miller KD, Jemal A (2015) Cancer Statistics, 2015. CA Cancer J Clin 65(1): 5-29.

2. Raina V, Tyagi BB, Manoharan N (2002) Cancer incidence and mortality in Delhi UT-urban. Delhi cancer registry. Dr. B.R. Ambedkar institute rotary cancer hospital, All India Institute of Medical Sciences. Scienceopen.com.
3. Wadhwa N, Mathew BB, Jatawa SK, Tiwari A (2013) Genetic Instability in urinary bladder cancer: An evolving hallmark. JPGM 59(4): 284-288.

4. Zaharieva BM, Simon R, Diener PA, Ackermann D, Maurer R, et al. (2003) High-throughput tissue microarray analysis of 11q13 gene amplification (CCND1, FGF3, FGF4, EMS1) in urinary bladder cancer. J Pathol. 201(4): 603-608.

5. Safarinejad MR, Safarinejad S, Shafiei N (2013) Association of genetic polymorphism of glutathione S-transferase (GSTM1, GSTT1, GSTP1) with bladder cancer susceptibility. Urol Oncol 31(7): 11931203.

6. Schnakenberg E, Lustig M, Breue R, Werdin R, Hübotter R, et al. (2000) Gender-specific effects of NAT2 and GSTM1 in bladder cancer. Clin Gen 2000; 57(4): 270-277.

7. Pandith AA, Shah ZA, Khan NP, Baba KM, Wani MS, et al. (2013) HRAS T81C polymorphism modulates risk of urinary bladder cancer and predicts advanced tumors in ethnic Kashmiri population. Urol Oncol 31(4): 487-492.

8. Kompier LC, Lurkin I, van der Aa NMN, van Rhijn BWG, van der Kwast TH, et al. (2010) FGFR3, HRAS, KRAS, NRAS and PIK3CA Mutations in Bladder Cancer and Their Potential as Biomarkers for Surveillance and Therapy. Plos ONE. 2010; 5(11): e13821.

9. Platt FM, Hurst CD, Taylor CF, Gregory WM, Harnden P, et al. (2009) Spectrum of phosphatidylinositol 3-kinase pathway gene alterations in bladder cancer. Clin Cancer Res 15(19): 6008-6017.

10. Fontana L, Lasfargues G, Ughetto S, Rogier S, Masdieu E, et al. (2001) The micronucleus assay in human exfoliated urothelial cells: application in a genotoxicity study of workers exposed to a mineral jelly containing sodium nitrite and N-phenyl-1-napthylamine. Mutagenesis 16(5): $449-452$.

11. Feng Z, Hu W, Rom NW, Beland FA, Tang MS (2002) 4-Aminophenyl is a major etiological agent of human bladder cancer: evidence from its DNA binding spectrum in human p53. Carcinogenesis 23(10): 17211727.

12. Phillips DH (2002) Smoking related DNA and protein adducts in human tissues. Carcinogenesis 23(12): 1979-2004.

13. Stern MC, Lin J, Figueroa JD, Kelsey KT, Kiltie AE, et al. (2009) Polymorphisms in DNA repair genes, smoking, and bladder cancer risk: findings from the international consortium of bladder cancer. Cancer Res 69(17): 6857-6864.

14. Lewis JD, Quesenberry CP, Ferrara A, Vaughn DJ, Peng T, et al. (2011) Risk of Bladder cancer among diabetic patients treated with Pioglitazone. Diabetes Care 34(4): 916-922.

15. Wang M, Li S (2013) Bladder polypoid cystitis-derived A20 associates with tumorigenesis. Cell Biochem Biophys 67(2): 669-673.

16. Reszka E, Jablonowski Z, Wieczorek E, Jablonska E, Krol MB, et al. (2014) Polymorphisms of NRF2 and NRF2 target genes in urinary bladder cancer patients. J Cancer Res Clin Oncol 140(10): 1723-1731.

17. Rouissi K, Ouerhani S, Marrakchi R, Ben Slama MR, Sfaxi M, et al. (2009) Combined effect of smoking and inherited polymorphisms in arylamine $\mathrm{N}$-acetyltransferase 2, glutathione S-transferases M1 and T1 on bladder cancer in a Tunisian population. Cancer Genet Cytogenet 190(2): 101-107.

18. Sauter G, Algaba F, Amin MB, Busch C, Cheville J, et al. (2004) Noninvasive urothelial tumors. In: Eble JN, Sauter G, Epstein JI, Sesterhenn IA (Eds.) WHO classification of tumours: pathology and genetics of tumours of the urinary system and male genital organs. Lyon: IARC Press.

19. Vishnu P, Mathew J, Tan WW (2011) Current therapeutic strategies for invasive and metastatic bladder cancer. Onco Targets Ther 4: 97-113.

20. National Cancer Institute’s SEER database 2015. 
21. Askham JM, Platt F, Chambers PA, Snowden H, Taylor CF, et al. (2010) AKT1 mutations in bladder cancer: identification of a novel oncogenic mutation that can co-operate with E17K. Oncogene 29(1): 150-155.

22. Knowles MA, Habuchi T, Kennedy W, Cuthbert-Heavens D (2003) Mutation spectrum of the 9q34 tuberous sclerosis gene TSC1 in transitional cell carcinoma of the bladder. Cancer Res 63(22): 76527656.

23. Oka N, Tanimoto S, Taue R, Nakatsuji H, Kishimoto T, et al. (2006) Role of phosphatidylinositol-3 kinase/Akt pathway in bladder cancer cell apoptosis induced by tumor necrosis factor-related apoptosisinducing ligand. Cancer Sci 97(10): 1093-1098.

24. Jun Xiao, Huan-Yi Lin, Yuan-Yuan Zhu, Yu-Ping Zhu, Ling-Wu Chen (2016) MiR-126 regulates proliferation and invasion in the bladder cancer BLS cell line by targeting the PIK3R2-mediated PI3K/Akt signaling pathway. Onco Targets Ther 9: 5181-5193.

25. Chen M, Gu J, Delclos GL, Killary AM, Fan Z, et al. (2010) 20 Genetic variations of the PI3K-AKT-mTOR pathway and clinical outcome in muscle invasive and metastatic bladder cancer patients. Carcinogenesis 31(8): 1387-1391.

26. Sfakianos JP, Gellert LL, Maschino A, Gotto GT, Kim PH, et al. (2014) The role of PTEN tumor suppressor pathway staining in carcinoma in situ of the bladder. Urol Oncol 32(5): 657-662.

27. Sidi GR, Iyer G, Solit D, Glickman MS (2013) Oncogenic activation of Pak1-dependent pathway of macropinocytosis determines BCG entry into bladder cancer cells. Cancer Res 73(3): 1156-1167.

\section{Your next submission with Juniper Publishers} will reach you the below assets

- Quality Editorial service

- Swift Peer Review

- Reprints availability

- E-prints Service

- Manuscript Podcast for convenient understanding

- Global attainment for your research

- Manuscript accessibility in different formats

( Pdf, E-pub, Full Text, Audio)

- Unceasing customer service

Track the below URL for one-step submission https://juniperpublishers.com/online-submission.php 